\title{
On the Ideological and Political Education of College Students in the New Media Era
}

\author{
Yan Yu \\ Polus International College, Chengdu, China \\ Email: yu.yan@polus.edu.cn
}

How to cite this paper: Yu, Y. (2022). On the Ideological and Political Education of College Students in the New Media Era. Open Journal of Social Sciences, 10, 1-14. https://doi.org/10.4236/jss.2022.101001

Received: November 25, 2021

Accepted: January 7, 2022

Published: January 10, 2022

Copyright $\odot 2022$ by author(s) and Scientific Research Publishing Inc. This work is licensed under the Creative Commons Attribution International License (CC BY 4.0).

http://creativecommons.org/licenses/by/4.0/

\begin{abstract}
With the advent of the new media era, in order to adapt to the changes of the times, the ideological and political education of College Students' work has also changed. Based on the importance of college students becoming talents, how to innovate ideological and political education in the new media era has become the focus of social attention. This paper first summarizes the characteristics of the new media era, and then analyzes the challenges and opportunities of new media technology in college students' Ideological and political education, as well as the current situation and changes of Ideological and political education in the new media era. Finally, on this basis, it tries to think about the effective path to improve the effectiveness of College Students' Ideological and political education in the new media era.
\end{abstract}

\section{Keywords}

New Media, College Student, Ideological and Political Education, Route

\section{Introduction}

The opinions of the CPC Central Committee and the State Council on strengthening and improving ideological and political work in Colleges and Universities under the new situation points out that we should focus on promoting the reform and innovation of Ideological and political work in Colleges and universities, vigorously strengthen the construction of Internet Ideological and political work carrier, and carry out ideological and political education by using the expression methods preferred by college students. Traditional ideological and political classroom teaching is the main way of College Students' Ideological and political education. Many college students have low interest in classroom teach- 
ing, and the educational effect is very limited. Therefore, in order to help college students establish a good ideological and political outlook, we must strengthen the political strength of College Students' Ideological and political education, explore new communication channels and modes, and organically combine with other disciplines, so as to effectively enhance the timeliness and acceptability of Ideological and political education. Colleges and universities not only shoulder the responsibility of Cultivating College Students' professional skills but also have the responsibility of cultivating their ideological and political quality and will quality. Therefore, it is necessary to think about carrying out college students' Ideological and political education in the new media era.

The author searched the related research on the theme of "Ideological and political education for college students in the new media era" on CNKI, and retrieved 483 relevant academic research papers. The earliest paper to study the ideological and political education for college students in the new media era is the ideological and political education for college students in the new media era published by Lin Aiqing in 2010. At present, there are many articles about The research theme of "Ideological and political education for college students in the new media era" has great relevance, and the representative research results are as follows: Xu Haixin and Liao Haojun published on the Academic Forum on how new media can play an effective role in Ideological and political education for college students, only $61 \%$ of teachers' normal use of new media is investigated, and the methods of improving media literacy education are analyzed from three aspects: media factors, social factors and college students' personal factors; Hong Yun published in the Journal of the National Institute of education administration, "Reflections on College Students' Ideological and political education in the new media era", after comparing the thoughts of Ideological and political education in western countries, this paper puts forward innovative path thinking on the ideological and political education of college students in China; long Nina, published in the analysis of innovative path of Ideological and political education of college students in the new media era, puts forward several paths to innovate the ideological and political education of college students, especially the introduction of "agenda setting", adhere to the socialist core value system to lead network public opinion; changes and Countermeasures of College Students' Ideological and political education in the new media era published by Chen Zhiyong in the guide of Ideological and theoretical education , compare the dialectical relationship between the change of Ideological and political education and tradition, and explore how to adhere to the essence and apply the change factors to improve the educational effect. At present, domestic researchers mostly discuss the innovative mechanism and ways from the perspective of practical work, mainly focusing on the mechanism, path innovative thinking and path exploration, especially focusing on the use of new media means to devote themselves to the thinking of college students There are many research results on the innovative ways of political education, but there is a lack of research on com- 
prehensively and systematically studying the characteristics of the new media era, analyzing the current situation of Ideological and political education in the new media era, combing the challenges and opportunities of College Students' Ideological and political education in the new media era, and making corresponding path exploration from theoretical to practical level. This paper attempts to make a more systematic analysis from the above levels.

\section{Overview of New Media}

With the development of Internet technology, the form and content of new media are expanding. For the extension of new media, domestic scholars especially recognized "digital TV, Internet TV (WebTV), online instant messaging group, chatwords, virtual community, blog podcast, search engine, RSS, e-mail, portal, SMS, color message, mobile TV, mobile radio, mobile service, mobile newspaper IPTV, etc.", Mobile phones have surpassed desktop computers as the first Internet terminals. The new media era has come, from web 1.0 to web 2.0. The interaction between teachers is constantly strengthened, and the gap between teachers is gradually filled (Huang, 2017). The audience has changed from the original information receiver to the information publisher and commentator. They can browse news and comments anywhere through mobile Internet tools. The advent of the Internet age has promoted people's social participation to be more active. With the popularity of mobile phones, computers and networks among college students, new media has deeply affected the ideology and behavior habits of contemporary college students, which has become an indisputable fact. According to the data report of QuestMobile in May 2020, the number of monthly live users of the whole network of mobile Internet has reached 1.164 billion. As the most active group of new media users, contemporary college students' study and life are inseparable from network media. Therefore, how to accurately grasp the new characteristics of College Students' Ideological and political work under the network new media environment and how to use the advantages of new media to correctly carry out college students' Ideological and political education is not only a new challenge but also a new topic to be solved in Colleges and universities.

\section{Characteristics of the New Media Era}

\subsection{The Information Environment Is Open}

This is the most prominent feature of the new media era. Everyone can act as a spokesman. For college students, the new media era has built an open expression platform for them to break through the limitations of time and space and speak freely on this open platform.

\subsection{Information Dissemination Is Immediate}

Traditional media use paper media such as magazines and newspapers for information dissemination, while the development of new media is based on In- 
ternet technology, which can transmit information in real time through major social applications such as microblog and wechat. Therefore, in the new media era, the speed of information dissemination is very fast, and the scope of dissemination is also very huge, which is basically spread to all social app users ( $\mathrm{Li}$, 2017).

\subsection{Information Dissemination Is Interactive}

This means that under the new media, people's role can be changed, not only for the disseminator of information but also for the receiver of information ( $\mathrm{Li}$ 2017). In the virtual space where massive information is stored, it is easy to realize the information search of the target theme, establish social relations with strangers, talk with friends all over the world, and the interest demands that are difficult to realize in the real physical world. Therefore, the new media has strong interactivity and can basically meet the interactive information needs of modern people.

\subsection{Rich Types of Information Dissemination}

In the new media era, everyone can freely express their views and opinions. At the same time, people can search the information they are interested in on the Internet, which makes the information content of new media have the characteristics of diversification. It can be divided into military, entertainment, politics, science and technology and economy. In addition, information diversification is also reflected in the form of information itself. For example, some information is transmitted through pictures, while others are transmitted through video or audio. Some people like WeChat' circle of friends as a way to spread information; some people like to use QQ space to spread information.

\section{Challenges and Opportunities of College Students' Ideological and Political Education in the New Media Era}

\subsection{Challenges to College Students' Ideological and Political Education in the New Media Era}

Represented by network media and mobile media, new media has the characteristics of convenient access, fast update speed and rich and colorful forms, and is welcomed by college students. However, the impact of new media has also brought challenges to the ideological and political education of college students. First of all, new media has brought a certain impact and adverse impact on College Students' thinking. In recent years, WeChat and new media represented by live broadcasting have developed rapidly and widely spread among college students. In a certain sense, these media have played a positive role in college students' acquisition of new knowledge and broadening their horizons, but some bad ideas they spread have also had a negative impact on College Students' thoughts to a certain extent. For example, the phenomena of showing off the rich, hating the rich and complaining about society widely publicized on We- 
Chat occur from time to time, and the phenomena involving pornography, gambling and drugs also occur from time to time in the live broadcast, which will have a negative impact on college students at the stage of forming their outlook on life, values and world outlook. Often read and read this information, it is easy to form misleading values of college students over a long period of time.

Secondly, new media is easy to cause college students' mental health problems. In addition to the impact of the above bad information, other new media situations cannot be ignored, which is easy to lead to college students' mental health problems. For example, some college students indulge in network social interaction due to unsatisfactory family or academic performance and seek a sense of survival and self-worth from the virtual society. Once this situation has been experienced for a long time, it will have an impact on the mental health of college students, may affect the normal social communication of college students, and may even produce emotions such as world fatigue or avoidance, resulting in mental health problems. The same situation is that online games are more serious. Once addicted to online games, it is easy to form internet addiction and even difficult to quit. Of course, there are only two main effects. In addition, it may also have an impact on integrity crisis and sedentary physical function.

\subsection{Opportunities for College Students' Ideological and Political Education in the New Media Era}

1) Promote the diversified development of College Students' Ideological and political education

In the early stage, due to the lack of educational resources, the ideological and political education in Colleges and universities mainly selected teaching contents from teaching materials, while the independent space of teaching practice was relatively narrow. The rapid development of new media information education provided a strong guarantee for the ideological and political education in Colleges and universities to make up for the lack of educational resources, so that the ideological and political education in colleges and universities can do a good job in-depth education optimization on the basis of different forms of education, Further improve the ideological and political education system of college students and improve the practical ability of stage education (Gao, 2015). In this process, ideological and political education in Colleges and universities breaks through the limitations of the development of traditional education, changes from theoretical education to practical education and training, effectively enhances the comprehensive ability of Ideological and political education in Colleges and universities and lays a solid foundation for the all-round development of Ideological and political education in Colleges and universities. At the same time, the continuous innovation of the application of new media technology also creates favorable conditions for the innovation of Ideological and political education in Colleges and universities, so that information media teaching can effectively design educational links around students' learning needs, change the 
main structure of the development of colleges and universities, and lay a good foundation for the development of colleges and universities.

2) Improve the timeliness and effectiveness of College Students' Ideological and political education

Through the research on the introduction to the basic principles of Marxism and the theory of socialism with Chinese characteristics, we can cultivate students' good core values and make them better contribute to the future social construction. With the change of College Students' ideas in the new era, the lag of college education contents and methods is becoming more and more prominent. Using the new media information technology reform to realize the effective improvement of the ideological and political education system in Colleges and universities in the new period has become the core focus of contemporary college students' work. At the same time, it also paves the way for the high-quality development of Ideological and political education in Colleges and universities. In addition, the use of new media information technology is oriented to the ideological and political education platform in Colleges and universities. In order to make the ideological and political education adapt to the new environment of educational development, we must make full preparations for the integration of Ideological and political education and the new environment.

3) New media has become a carrier to stimulate students' self-management consciousness

With the help of the platform of new media, students can independently carry out a series of theme activities. On the one hand, they can show students' work achievements in class; on the other hand, they also play a good role in publicity and communication. In Ideological and political education, guide students to create a good atmosphere beyond students. On the other hand, through the establishment of microblog, QQ group and class blog circle of class or student organization, everyone can become the online administrator of class or student organization and participate in the management of organizational affairs. This can improve the enthusiasm and participation of college students in affairs management. There is no doubt that the highest level of student management is to realize students' self-management, self-education and self-discipline, and new media has solved this problem well.

\section{Analysis of the Current Situation of College Students' Ideological and Political Education in the New Media Era}

\subsection{New Media Has a Double-Sided Influence on the Reform of Ideological and Political Work}

At present, with the continuous development of politics, economy and science and technology, the ideological and political education of college students is also developing. However, in the new media era, the ideological and political education of college students is in trouble. On the one hand, new media has brought great opportunities to college students' Ideological and political education. 
Making good use of it can effectively promote the progress and innovation of Ideological and political education, and make it more in line with the needs of real society and college students. For example, new media has created an open information interaction platform for college students. Students can not only freely express their views and opinions on this platform, but also find the information resources they need. Using this platform can interact with students, guide students' value orientation, and enhance students' learning desire, ideological and political education, so as to achieve better results in the classroom. On the other hand, the bad information of new media is easy to induce students to degenerate, form wrong values and hinder the ideological and political education of college students. In addition, the new media era also has a certain impact on the reform of Ideological and political education in Colleges and universities, sometimes leading to the contradiction between the new model and the traditional model. Therefore, it is necessary for relevant personnel to make good use of new media to promote the good development of Ideological and political education.

\subsection{The New Media Era Puts forward Innovative Requirements for College Students' Ideological and Political Education}

First, college students' Ideological and political education needs to shift the basic focus. The development of information technology in the new media era has a direct impact on college students. To carry out ideological and political education in Colleges and universities, we must innovate the content of Ideological and political education according to the basic characteristics of the new media era. The shift of the focus of work in Colleges and universities is essentially the optimization of the ideological and political education system of contemporary college students. The traditional outlook on the development of Ideological and political education mainly focuses on the education layout from the perspective of teachers. In ideological and political education, the needs of College Students' education and learning are not taken into account. In the new media era, college students' Ideological and political education organizes education work from the dimension of cultivating students' autonomous learning ability and improving students' learning initiative, so as to fundamentally improve their initiative to participate in Ideological and political learning, Make them actively integrate into the educational practice environment, better improve the mechanism of Ideological and political education in Colleges and universities, play an important role in cultivating college students' good outlook on life, and play a positive role in improving the quality of life, quality of life, values and social outlook (Liu, 2014). Second, the content of the ideological and political education system in Colleges and universities needs to keep pace with the times and innovate, which is the basic new environment for the ideological and political education in Colleges and universities to adapt to the development of education. By constructing a complete college students' knowledge system, college students can 
actively integrate into the education and learning environment, better help students get rid of learning difficulties, offset the impact of bad social information on college students, and lay a solid foundation for the in-depth practice of College Students' Ideological and political education (Deng, 2011).

\subsection{It Is Feasible for Colleges and Universities to Carry Out Ideological and Political Work with the Help of New Media}

Combined with the characteristics of new media and the methods and means of Ideological and political work in Colleges and universities, we can see that it is feasible for colleges and universities to carry out ideological and political work with the help of new media. First, new media can carry various forms of information and rich content information. The subjects of Ideological and political activities can spread educational content only by registering an account. For example, WeChat is an all-around social platform based on acquaintances. Information can be transmitted by more than one pair of mass communication, a certain scale of group communication and point-to-point human communication in WeChat, so as to make the information flow faster through publishing, retrieval, forwarding and other functions. Tiktok is the largest video social networking platform in China and is also an important platform for young people to record daily life and visual performance. The main body of Ideological and political activities can influence the guests of Ideological and political activities by publishing positive energy videos. Video music provides templates from the platform, which is simple and easy to operate. Second, because the essential characteristics of new media are interactivity and sociality, information realizes two-way, nonlinear and interactive communication, information disseminators and recipients can communicate in real-time, and the relationship between people and people and organizations becomes closer, which can realize the effective relationship with the subject and object of Ideological and political work.

\section{Thoughts on Innovating College Students' Ideological and Political Education in the New Media Era}

In the new media era, college students' Ideological and political education needs to make corresponding path exploration from theory to practice. In theory, it is necessary to do a good job in the Connotation Design of Ideological and political education, adhere to the socialist core values, and innovate the relevant working mechanism of College Students' Ideological and political education in the new media era, improve the Marxist theoretical literacy of Ideological and political workers in Colleges and universities and the application level of new media; In practice, we need to build a new media platform related to ideological and political education in Colleges and universities, promote the full integration of new media online and offline, build a new media team for college students' Ideological and political education in an all-round way, and give full play to the positive role of college students as the main body of education. 


\subsection{Adhere to the Core Values of Socialism and Strengthen the Theme of Ideological and Political Education}

Politics should become the theme of Ideological and political education in the new media era. As a socialist country, college students' Ideological and political education must adhere to the guiding ideology of Marxism; adhere to the people-oriented scientific outlook on development and socialist core values with socialism as the mainstream. For the whole ideological and political education work, we should formulate communication design scheme and education plan according to the law of new media communication, and improve the system construction level of new media education. Integrate the socialist core values into the content and form design of Ideological and political education. We should resolutely resist the erosion of negative thoughts and ensure a pluralistic and harmonious university culture. At the same time, the ideological and political work in Colleges and universities should make full use of the advantages of new media, use a variety of communication means, create new communication forms, spread the concept of harmony, make the socialist core values become the "soul" of culture, widely spread and deeply implemented in the study and life of college students. Introduce the concept and model of new media governance. Promote the construction of network legal system, establish a team of network inspectors, grasp public opinion at any time, strengthen the management of new media, and occupy the main position of ideological function.

\subsection{Construction of Working Mechanism of College Students' Ideological and Political Education in the Era of Innovative New Media}

We should seize the ideological and political education opportunities for college students created in the new media era, constantly improve the convenience of using the emerging network communication platform to disseminate information, innovate lively forms that meet the acceptance psychology of college students, and constantly enrich the healthy, positive and upward new media communication content, Form a substantive mechanism for Innovating College Students' Ideological and political education in the new media era. It is of great significance to innovate the content of University Ideological and political education system and comprehensively promote the construction of University Ideological and Political Education (new media). College students' Ideological and political education should tend to enrich the content of education and education management, reform the form of education, make college students interested in Ideological and political education, and guide college students to constantly explore the theoretical concept of Ideological and political education with the help of multiple educational methods, So as to cultivate college students' positive political thinking and improve their understanding of Ideological and political education knowledge. At the same time, we must adhere to the student-oriented education concept, stimulate the enthusiasm, initiative and initiative of college students, let them consciously integrate into various activities of Ideological and 
political education, change them from the passive recipient of Ideological and political education to the master of Ideological and political education, and form the subjective mechanism of innovative ideological and political education in the new media era.

\subsection{Strengthen the Marxist Theoretical Literacy and the Application Level of New Media of Ideological and Political Workers in Colleges and Universities}

In the new media era, it is necessary to continuously improve the Marxist theoretical literacy of College Students' Ideological and political educators, so as to make them more persuasive in the analysis and anatomy of various social thoughts, social phenomena and social problems, so as to play a correct guiding role in college students' Ideological and Political Education. Educators must be educated first. College Students' thinking

Only when political educators have rich knowledge, can they get rid of the preaching of abstract and general, empty and shallow, and poor thought, so as to be guided, analyzed deeply and explained thoroughly, and achieve substantive results in the ideological and political education of college students, so as to build a team that truly believes, understands, practices and practices Marxist theory The real team of Ideological and political educators plays a guiding role in the ideological and political education of college students in the new media era.

At the same time, there are many new media means in the new media era. There are many new media forms derived from the Internet, mobile phones and games. The development of each new media tool is specifically aimed at a specific group of people. College students will choose multiple new media forms to intervene in their own life according to their own interests. Tiktok students are interested in short video transmission software such as jitter, Kwai Fu, Xiao Hong and so on. They should have a strong interest in changing the concept and mastering skills. The teachers of Ideological and political education should learn to master different types of new media tools, and understand their network language, habits and inclination of using network. Be familiar with different types of new media and network usage norms, leave no network dead corner for communication with college students, constantly shorten the distance with the educated, and understand various factors that have a great impact on College Students' Ideological and political education, so as to strengthen the management of new media types and network usage norms through guidance, discussion, symposium, class meeting and other forms, Carry out targeted new media ideological and political education.

\subsection{Build a New Media Platform Related to Ideological and Political Education in Colleges and Universities to Promote the Full Integration of New Media Online and Offline}

In the new media era, college students who are willing to accept new things bas- 
ically have mobile devices. Mobile phones and other mobile devices have changed the traditional way of face-to-face or telephone communication. The school should actively build a campus network platform to timely fill and put in place the digital position of College Students' Ideological and political education in the new media era and the virtual space in the new media era. Students can use WeChat, microblog and other applications on mobile phones to interact anytime, anywhere. Therefore, colleges and universities should actively build an exchange platform related to ideological and political education by using new media to guide students to freely express their views and opinions and pay attention to them. In addition, colleges and universities should pay attention to standardizing the atmosphere of students' various communication platforms and actively guide students' thoughts to develop in the right direction. Specifically, we can use WeChat official account to build a platform for the exchange of Ideological and political content between teachers and students. Guide students to pay attention to current political information app; organize students to learn ideological and political courses online and other relevant measures to build.

At the same time, the new media work should be "offline" and "online", which not only has real space, but also needs to build a digital campus in the new media space such as microblog and WeChat. The effect of any form of education is not as good as face-to-face communication with students. In the real world, the traditional way of Ideological and political education can effectively promote the development of online and virtual world education. Only by forming a joint force online and offline can we get a better effect. In the digital campus, the real relationship between alumni and teachers and students can be maintained, and the whole campus society is flat, symbolic and grid. The whole organizational structure of the university presents a situation of multiple simultaneous developments, such as class groups, college and department groups, student organization system, teaching information platform, school comprehensive service platform and so on. Ji (2014) build a new space for ideological and political education in Colleges and universities. For example, achieving the purpose of Ideological and political education through teachers' online blogs, counselors' personal websites and some packaging are effective methods and models to lead college students' Ideological and political education in the new media era.

\subsection{Build a New Media Team for College Students' Ideological and Political Education in an All-Round Way}

First, we should actively build an "expert" team for college students' Ideological and political education in the new media era. The rapid development of new media technology puts forward new requirements for the ability and quality of College Students' Ideological and political educators. We should not only establish a keen information consciousness and master advanced technical means, but also be familiar with the popular network language. Only in this way can we have a dialogue with college students and seek resonance, so as to achieve the goal of enlightening thought and value guidance. The massive information of 
virtual space and the timeliness of new media have greatly weakened the information advantages of Ideological and political educators. If ideological and political educators still stay at the level of "knowing the nature" of problem events and simple preaching in the form of slogans, they obviously cannot realize the ideological guidance and public opinion guidance for college students. This requires us to make greater efforts to improve the theoretical level, political level and policy level, enhance the "depth" and "thickness" of our theoretical accumulation, and use solid theoretical foundation and rich analytical perspective to deeply interpret all kinds of social problems and social events.

Second, we should build a high-quality new media team among student cadres. Student cadres are advanced elements among college students, have high comprehensive quality, and are the bridge and link between educators and students. Student cadres themselves are produced from student groups. They are familiar with students, and their views and ideas are easy to be accepted by students. It is particularly important and necessary to do a good job in students' Ideological and political education, which is conducive to expanding the scope of work. Space ideological and political education is also conducive to improving work effectiveness and training student cadres. How to organize a team of high-quality student cadres? First, new media should select high-quality, capable and responsible student cadres to participate in the team. Second, strengthen training and learning, enhance students' risk awareness of the ideological function of new media, and improve their vigilance to negative ideas. Through case analysis and simulation exercises, strengthen business learning in the new media environment and improve the working ability of student cadres. Third, improve the assessment system, stimulate the enthusiasm of student cadres through assessment, and adopt more positive assessment methods in assessment in combination with the characteristics of candidates.

Third, we should pay attention to the attention and training of College Students' opinion leaders on the Internet. There are such a small number of college students who may be silent and implicit in real life and dare not express their views and opinions. However, in the virtual world of the Internet, many of their inner knowledge and emotions have been fully expressed and brought into play. Their views and actions are the object pursued and imitated by many college students, this kind of people become network opinion leaders. College Ideological and political education should pay special attention to the attention and cultivation of such people. The guidance of network opinion leaders for positive mainstream ideas and public opinion will play a significant role in promoting college students' Ideological and political education. If network opinion leaders are manipulated and bewitched by some illegal forces, the consequences are also very serious.

\subsection{Give Full Play to the Positive Role of College Students Themselves as the Main Body of Education}

Ideological and political educators should establish the concept of student- 
oriented, and put college students as the subject rather than the object in the first place of Ideological and political education. Rely on, respect and encourage students, and let them enter the perspective of Ideological and political education as subjects. Ideological and political education is related to the change of people's practical behavior. Ideological and political education should play a role. The internal reason lies in the change of College Students' own behavior so that college students can achieve the purpose of "unity of knowledge and practice" through ideological and political education. If we do not give full play to the main role of college students in ideological and political education, the ideological and political education can only stay at the level of indoctrination and preaching, and cannot achieve the effect of internalizing the thoughts and souls of college students, let alone changing the behavior and practice of college students. This requires college students not only to learn self-education and self-service in school but also to grasp the subjective ability that must be possessed by life, understand society and read life after they go to society. Therefore, there is an urgent need for ideological and political educators to strengthen college students' Ideological and political education according to the reality of network dependence in the new media era, so that students can master the correct world outlook and methodology, so as to help them walk a stable, good and right road.

\section{Conclusion}

In the new media era, college students' Ideological and political education has added many convenient tools and channels. However, the spread of negative news will also bring negative effects, which is not conducive to the good progress of Ideological and political education. Therefore, the new media era is both an opportunity and a challenge for college students' Ideological and political education. In this context, in order to better complete the ideological and political education of college students, school educators must actively adjust and innovate educational methods and contents according to the characteristics of the times. Only by recognizing the connotation and significance of College Students' Ideological and political education in the new media era, can we explore the methods and paths of Ideological and political education in line with the reality and the requirements of the times, and help college students' Ideological and political education develop in the right direction.

\section{Conflicts of Interest}

The author declares no conflicts of interest regarding the publication of this paper.

\section{References}

Deng, Q. W. (2011). Research on the Influence of New Media on College Students' Ideology and Morality and Its Countermeasures. Master's Thesis, Guangxi Normal University.

Gao, Z. J. (2015). On the Influence and Function of New Media on College Students' 
Ideological and Political Education. China Newspaper Industry, No. 20, 93-94.

Huang, S. (2017). Thoughts on Ideological and Political Education for College Students in the New Media Era. Educational Modernization, No. 3, 257-258.

Ji, H. J. (2014). Deconstruction and Reconstruction of Ideological and Political Education in Colleges and Universities in the New Media Era. Southeast University Press.

Li, H. F. (2017). Reflections on College Students' Ideological and Political Education in the New Media Era. Modernization of Education, No. 7, 195-196.

Liu, Z. P., \& Shao, K. X. (2014). The Influence of New Media On College Students' Ideological and Political Education and Its Countermeasures. Journal of Chifeng University (Natural Science Edition), No. 1, 196-197. 